ISSN 0206-5657. Вісник Львівського університету. Серія біологічна. 2018 Випуск 78. С. 60-65 Visnyk of the Lviv University. Series Biology. 2018. Issue 78. P. 60-65

УДК 581.93+58.087

\title{
ENDEMIC PLANTS OF THE UKRAINIAN CARPATHIANS IN KAREL DOMIN'S CARD INDEX
}

\author{
A. Novikov \\ State Natural History Museum, NAS of Ukraine \\ 18, Teatralna St., Lviv 79008, Ukraine \\ e-mail:novikoffav@gmail.com
}

\begin{abstract}
Karel Domin was a famous Czech botanist of the beginning of 20th century, significantly contributed to investigations of the flora of Carpathian region. Apart from huge herbarium collection and number of published scientific papers, he left for progenies the card index indicating the distribution of different plant taxa on the territory of former Czechoslovakia. This card index was developed during the preparation of determination key of plants of Czechoslovakia and currently it is hosted at the Institute of Botany CAS in Průhonice (Czech Republic). Another outstanding botanist, Ján Futák made a copy of that part of Domin's card index, which represented taxa distributed in Slovakia region (including the Podkarpatská Rus region currently belonging to Ukraine) and deposited this copy at the Institute of Botany SAS in Bratislava (Slovakia). In February $2018 \mathrm{I}$ had a pleasure to work with Domin's card index hosted in Bratislava. I had gathered from there the data about distribution of endemic plant taxa in flora of the Ukrainian Carpathians. These data are important source of information for further biogeographical studies since they allow evaluating and simulating the patterns of spatial distribution. In total I elaborated and digitized 336 cards for 55 endemic plant taxa distributed in the Ukrainian Carpathians and built the database containing 1674 entries with implication of the main phytogeographical units. In this index I had also found cited localities from some regions of the Ukrainian Carpathians that have never been mentioned in Ukrainian papers before and generally were overlooked by scientists. In particular, Heracleum sphondylium subsp. transsilvanicum was rediscovered for Marmarosh and Svydovets (before it was cited only for Chornohora and Chyvchyny), Koeleria macrantha subsp. transsilvanica was rediscovered for Marmarosh (there were no details about distribution of this taxon in theUkrainian Carpathians before), Noccaea dacica was rediscovered for Cornohora (before it was cited only for Svydovets), Oxytropis carpatica was rediscovered for Chorhohora, Scorzoneroides pseudotaraxaci was rediscovered for Chornohora and Gryniava (before it was cited only for Svydovets), and Trifolium sarosiense was rediscovered for Chornohora and Svydovets (there were no details about distribution of this taxon in the Ukrainian Carpathians before). Hence, in the Ukrainian Carpathians occur at least 76 endemic and subendemic taxa, and three more taxa (Dianthus spiculifolius, Leucanthemopsis alpina and Trisetum macrotrichum) are most probably absent in this region.
\end{abstract}

Keywords: Karel Domin, endemics, biogeography, plant conservation, Carpathians

\section{Introduction}

Karel Domin (1882-1953) was one of the famoust Checz botanists of the 20th century specialized on floristics, geobotany and nature conservation. He was the key person in creation of Czech Botanical Society in 1912, Carpathian Geobotanical Union in 1925 and Tatra National Park in 1926 [16]. He also established and published from 1920 till 1945 the journal "Věda Prŕrodní". He is also widely known by investigations on the flora of Queensland, which he visited in 1909-1910 during his expedition to Java and Australia. After returning to Prague he worked at Charles University and received position of professor of botany in 1916. In 1922-1923 he had a

(C) Novikov A., 2018 
position of a dean of the faculty of natural sciences, and in 1933-1934 even reached the position of the rector of the Charles University [3]. However after WWII he was fall into oblivion due his ultraright political views and has no right to provide a scientific work. Nevertheless, after his exile he contributed significantly to investigations of flora of Czech Republic and adjacent regions, including the recent territories of the Ukrainian Carpathians. In particular, he created the card index containing the literature citations and personal observations for almost all plant taxa distributed in these regions [8]. This card index was developed during the work on determination key of plants of Czechoslovakia and the book "Bibliografia k flóre CSR", and currently is hosted at the Institute of Botany CAS in Průhonice (Czech Republic). Later Ján Futák made a copy of that part of the card index representing the taxa from Slovakia and deposited this copy at the Institute of Botany SAS in Bratislava (Slovakia).

The investigations on endemic plant taxa distributed in the Ukrainian Carpathians have a long history and still are in actual trend of research [1, 2, 4, 6, 9, 11, 13, 14]. Endemics are crucial element characterizing the local floras and laying at the base of delimitation of biogeographical units and playing the main role in conservation policies [7, 11, 15]. Among the main problems targeted in these studies were the status and validity of some problematic taxa, as well as phytogeographical patterns of their distribution and evolution. It is very important not only to know the current distribution of endemic taxa, but also to have previously registered observations allowing spatial and chronological conclusions. Therefore here I am representing the data about presence of endemic plants in flora of the Ukrainian Carpathians gathered from the card index of Karel Domin hosted at the Institute of Botany SAS in Bratislava, Slovakia.

\section{Material and methods}

The studies were conducted in February 2018 during my research stay at the Institute of Botany SAS in Bratislava supported by SAIA foundation (The National Scholarship Programme of the Slovak Republic for the Support of Mobility of Students, PhD Students, University Teachers, Researchers and Artists). As a result, there were scanned, digitized and databased 1674 entries from 336 cards of this index. The database was supported by delimitation of main phytogeographical units of the Ukrainian Carpathians [6, 11, 12], and later will be completed with information on data age and GPS coordinates for all entries. In total, the gathered data represent 55 of 79 endemic plant taxa distributed in the Ukrainian Carpathians.

\section{Results and discussion}

Here I represent the brief list of endemic plant taxa distributed in the Ukrainian Carpathians based on the analysis of Domin's card index with respect to the presene in the phytogeographical regions. Also I provide the shortened citations for rediscovered locations for selected taxa.

Endemics of the South-Eastern Carpathians: 1) Achillea oxyloba subsp. schurii (here and later in text in the round brackets, chorology based on the Domin's card index - Chornohora, Marmarosh, Svydovets); 2) Aconitum bucovinense (not indexed); 3) Alopecurus pratensis subsp. laguriformis (not indexed); 4) Armeria pocutica (extinct in Ukraine [5]; not indexed); 5) Centaurea rodnensis (Svydovets); 6) Chrysosplenium alpinum (Chornohora, Marmarosh, Svydovets); 7) Cyanus maramarosiensis (Chornohora, Polonynas, Svydovets); 8) Dianthus spiculifolius (not indexed); 9) Doronicum carpaticum (Chornohora, Gryniava, Marmarosh, Svydovets); 10) Erysimum witmanni subsp. transsilvanicum (not indexed); 11) Festuca porcii (Chornohora, Marmarosh); 12) Festuca versicolor subsp. dominii (not indexed); 13) Galium album subsp suberectum (not indexed); 14) Galium transcarpaticum (not indexed); 15) Genista tinctoria subsp. oligosperma (Marmarosh); 16) Gentiana laciniata (Chornohora, Gryniava, Marmarosh, Polonynas, Svydovets); 17) Gymnadenia carpatica (not indexed); 18) Heracleum 
carpaticum (Chornohora, Marmarosh); 19) Heracleum sphondylium L. subsp. transsilvanicum (Marmarosh, Svydovets, Chornohora and Chyvchyny); 20) Koeleria macrantha subsp. transsilvanica (Marmarosh); 21) Leontodon kulczynskii (not indexed); 22) Melampyrum saxosum (Chorhohora, Chyvchyny, Marmarosh, Polonynas, Svydovets); 23) Noccaea dacica (Cornohora, Svydovets); 24) Phyteuma tetramerum (Chorhohora, Chyvchyny, Eastern Beskyds, Gryniava, Marmarosh, Svydovets); 25) Phyteuma vagneri (Chorhohora, Chyvchyny, Gorgany, Marmarosh, Polonynas, Svydovets); 26) Poa granitica subsp. disparilis (Chorhohora, Gorgany, Marmarosh, Svydovets); 27) Poa rehmannii (not indexed); 28) Pulmonaria filarszkyana (Chornohora, Chyvchyny, Gorgany, Marmarosh, Polonynas, Svydovets, Volcanic Carpathians); 29) Ranunculus carpaticus (Chornohora, Marmarosh, Polonynas, Svydovets); 30) Ranunculus malinovskii (not indexed); 31) Saussurea porcii (not indexed); 32) Scabiosa lucida subsp. barbata (not indexed); 33) Senecio ucranicus (not indexed); 34) Sesleria bielzii (Chornohora, Gorgany, Gryniava, Svydovets); 35) Silene nutans subsp. dubia (Chornohora, Chyvchyny, Gorgany, Gryniava, Marmarosh, Polonynas, Svydovets); 36) Silene zawadzkii (not indexed); 37) Syringa josikaea (Eastern Beskyds, Polonynas); 38) Thymus alternans (Volcanic Carpathians); 39) Trisetum macrotrichum (in the Ukrainian Carpathians it is absent [17]; not indexed); 40) Viola declinata (Chornohora, Chyvchyny, Gorgany, Gryniava, Marmarosh, Polonynas, Svydovets).

Subendemics of South-Eastern Carpathians: 1) Crocus banaticus (Chornohora, Marmarosh); 2) Swertia punctata (Chornohora, Marmarosh); 3) Viola jo (in the mountain regions it is absent but sometimes occurs in adjacent lowlands [5, 10, 11]; not indexed).

Pancarpathian endemics: 1) Antennaria carpatica (Chornohora, Polonynas, Svydovets); 2) Arabidopsis neglecta (Chornohora, Marmarosh, Svydovets); 3 ) Campanula carpatica (Chornohora, Marmarosh, Svydovets); 4) Campanula serrata (Chornohora, Gorgany, Eastern Beskyds, Marmarosh, Polonynas, Svydovets); 5) Campanula tatrae [incl. C. kladniana and C. rotundifolia subsp. polymorpha]. (C. tatrae taxon was sometimes mentioned for the Ukrainian Carpathians, but there were no any details about its locations [6]; Chornohora, Marmarosh, Polonynas, Svydovets); 6) Leucanthemopsis alpina subsp. tatrae (not indexed); 7) Leucopoa carpatica (Chorhohora, Chyvchyny, Gorgany, Marmarosh, Svydovets); 8) Luzula alpinopilosa subsp. obscura (Chorhohora, Gorgany, Gryniava, Marmarosh, Svydovets); 9) Minuartia pauciflora (Chorhohora, Gryniava, Marmarosh, Svydovets); 10) Oxytropis carpatica (Chorhohora; some authors believe that it is currently extinct in the Ukrainian Carpathians [6]); 11) Plantago atrata subsp. carpatica (Svydovets); 12) Poa nemoralis subsp. carpatica (not indexed); 13) Pyrola carpatica (Chornohora, Svydovets); 14) Salix kitaibeliana (Chornohora, Svydovets); 15) Scorzoneroides pseudotaraxaci (Chornohora, Gryniava, Svydovets); 16) Sempervivum carpathicum subsp. carpathicum (Chornohora, Marmarosh, Polonynas, Svydovets); 17) Sesleria heuflerana subsp. heuflerana (Chornohora, Svydovets); 18) Symphytum cordatum (Chornohora, Eastern Beskyds, Gorgany, Marmarosh, Polonynas, Svydovets, Volcanic Carpathians); 19) Thymus pulcherrimus subsp. pulcherrimus (Chornohora, Marmarosh, Polonynas, Svydovets); 20) Trisetum fuscum (Chornohora, Marmarosh, Svydovets).

Pancarpathian subendemics: 1) Aconitum firmum (Chornohora, Gorgany, Marmarosh, Polonynas, Svydovets); 2) Aconitum lasiocarpum (not indexed); 3) Aconitum moldavicum (Chornohora, Chyvchyny, Gorgany, Gryniava, Marmarosh, Polonynas, Svydovets, Volcanic Carpathians); 4) Cardamine glanduligera (Chornohora, Chyvchyny, Gorgany, Eastern Beskyds, Marmarosh, Polonynas, Svydovets, Volcanic Carpathians); 5) Euphrasia tatrae (Chornohora, Gorgany, Marmarosh, Polonynas, Svydovets); 6) Festuca versicolor subsp. versicolor (not indexed); 7) Jovibarba globifera subsp. preissiana (Marmarosh); 8) Lathyrus transsilvanicus (Volcanic Carpathians); 9) Leucanthemum rotundifolium (Chorhohora, Chyvchyny, Eastern 
Beskyds, Gorgany, Marmarosh, Polonynas, Svydovets); 10) Linum extraaxilare (Chornohora, Gorgany, Gryniava, Marmarosh, Polonynas, Svydovets); 11) Poa pannonica subsp. scabra (Volcanic Carpathians); 12) Scilla kladnii (not indexed); 13) Trifolium sarosiense (Chornohora and Svydovets - rediscovered locations).

Endemics of unclear range: 1) Festuca amethystina subsp. orientalis (probably is a subendemic of SE Carpathians; not indexed); 2) Minuartia verna subsp. oxypetala (probably is an endemic of SE Carpathians; not indexed); 3) Soldanella marmarossiensis Klast. [incl. Soldanella hungarica] (unclear distribution; Chornohora, Marmarosh, Polonynas, Svydovets).

\section{Conclusions}

As a result of our study we can conclude that in flora of the Ukrainian Carpathians there are at least 76 endemic plant taxa. Three more endemic taxa (Dianthus spiculifolius, Leucanthemopsis alpina and Trisetum macrotrichum) are most probably absent in the Ukrainian Carpathians and were not observed in Domin's card index. From other side, here we cite the rediscovered from the Domin's card index locations for several other species that were usually overlooked by Ukrainian scientists and not mentioned in recent publications. In particular, our analysis of card index revealed the presence in the Ukrainian Carpathians (at least in previous times) of Koeleria macrantha subsp. transsilvanica (Marmarosh) and Trifolium sarosiense (Chornohora and Svydovets). Also, in the Domin's card index we have found cited some new locations for the taxa that usually were mentioned for other regions of the Ukrainain Carpathians. In particular, Heracleum sphondylium subsp. transsilvanicum, beside of all, in the Domin's card index is cited also for Marmarosh and Svydovets, Noccaea dacica and Oxytropis carpatica - for Chornohora, and Scorzoneroides pseudotaraxaci - for Chornohora and Gryniava.

\section{REFERENCES}

1. Котов М.И., Чопик В.И. Основные черты флоры и растительности Украинских Карпат // Флора и фауна Карпат. М.: Изд-во АН СССР, 1960. С. 3-33.

2. Малиновський К., Царик Й., Кияк В., Нестерук Ю. Рідкісні, ендемічні, реліктові та пограничноареальні види рослин Українських Карпат. Львів: Ліга-Прес. 2002. 76 с.

3. Мигаль А.В., Шевера М.В. Домін Карел // Енциклопедія сучасної України. К.: НАН України, 2008. Т. 8. С. 251.

4. Тасєнкевич Л. Розмаїття флори судинних рослин в Українських Карпатах // Праці Наук. т-ва ім. Т. Шевченка. 2003. Т. 12. С. 145-157.

5. Червона книга України. Рослинний світ / під ред. Я.П. Дідуха (ред.). К.: Глобалконсалтинг, 2009. 900 с.

6. Чопик B.I., Федорончук M.М. Флора Українських Карпат. Тернопіль: Терно-граф, 2015. $712 \mathrm{c}$

7. Чорней I.I. До питання про ендемізм флори Українських Карпат // Заповідна справа в Україні. 2006. Т. 12. № 2. 7-16.

8. Krahulec F. Karel Domin (1882-1953) // Živa. 2012. Vol. 4. P. 65-66.

9. Kricsfalusy V.V., Budnikov G.B. Endemic vascular plants in the Ukrainian Carpathians // Mountains and people. In context of sustainable development: Proc. of Int. Conf. Rakhiv. 2002. P. 356-360.

10. Niketić M., Cikovac P., Barina Z., Pifkó D., Melovski L., Duraki Š., Tomović G. Viola chelmea and Viola jooi (Violaceae), new species for the flora of Serbia and their distribution in the Balkan peninsula and the Carpathians // Bulletin of the Natural History Museum of Belgrade. 2015. Vol. 8. P. 49-74. 
11. Novikoff A.V., Hurdu B.-I. A critical list of endemic vascular plants in the Ukrainian Carpathians // Contrib. Bot., Cluj-Napoca. 2015. Vol. 50. P. 43-91.

12. Novikov A., Hurdu B.I. Geomorphologic division of the Ukrainian Carpathians for routine use in biogeography // Biogeography of the Carpathians: Ecological and evolutionary facets of biodiversity: proc. of the second interdisciplinary symposium (Cluj-Napoca, 28-30 September 2017) / Studia Universitatis Babeş-Bolyai, Biologia. 2017. Vol. 62 (Sp. Iss.): 172-173.

13. Pawłowski B. Ogolna charakterystyka geobotaniczna gor Czywczynskich // Rozprawy wydzialu mat.-przyrodniczego. Kraków: Polsk. akad. Umiej. 1948. S. 1-72.

14. Pax F. Grundzüge der Pflanzenverbreitung in den Karpathen. Bd. I \& II. Leipzig. 1898-1908. $564 \mathrm{~S}$.

15. Tasenkevich L. Regional phytogeografical division of the Carpathians // Roczniki Bieszczadzkie. 2005. Vol. 13. P. 15-28.

16. Wójcik Z.J. O polskich badaniach geologicznych w Karpatach Słowackich w okresie międzywojennym // Kwart Hist. Nauki i Techn. 1985. R. 30. S. 672-673.

17. Zapałowicz H. Conspectus florae Galiciae criticus. Kraków: Nakładem Akad. Um. 1906. P. 35-36.

\title{
ЕНДЕМІЧНІ РОСЛИНИ УКРАЇНСЬКИХ КАРПАТ У КАРТОТЕЦІ КАРЕЛА ДОМІНА
}

\author{
А. Новіков \\ Державний природознавчий музей НАН України \\ вул. Театральна, 18, Львів 79008, Україна \\ e-mail:novikoffav@gmail.com
}

\begin{abstract}
Карел Домін - видатний чеський ботанік початку XX ст., який значною мірою долучився до досліджень флори Карпатського регіону. Окрім величезної колекції гербарного матеріалу і числа опублікованих праць, у спадок він також залишив картотеку, що містить детальну інформацію про поширення рослин на території колишньої Чехословаччини. Цю картотеку він створив під час роботи над визначником рослин Чехословаччини, і на сьогодні вона зберігається в Інституті ботаніки ЧАН у Пругоніце (Чехія). Інший відомий ботанік Ян Футак створив копію частини картотеки Доміна, яка стосувалася таксонів, поширених на території Словаччини (включаючи ділянку Підкарпатської Русі, яка на сьогодні входить до складу України). Ця копія на сьогодні зберігається в Інституті ботаніки САН у Братиславі (Словаччина). У лютому 2018 р. я мав нагоду опрацювати картотеку Карела Доміна, що зберігається у Братиславі, та зібрати дані щодо представлення ендемічних таксонів рослин у флорі Українських Карпат. Ці дані є важливим джерелом для подальших біогеографічних досліджень, оскільки є підставою для оцінки та моделювання просторового розподілу ендемічних рослин у Карпатах. Загалом я опрацював 336 карт для 55 ендемічних таксонів і створив робочу базу даних, яка містить 1674 записи з розподілом по основних фітогеографічних районах Українських Карпат. У результаті проведеної роботи мені також вдалося виявити локалітети в межах Українських Карпат, які раніше не згадувалися в українських публікаціях і працях більшості іноземних дослідників. Зокрема, віднайдено посилання на локалітети Heracleum sphondylium subsp. transsilvanicum у Мармароші та на Свидівці (раніше наводився лише 3 Чорногори i Чивчин), Koeleria macrantha subsp. transsilvanica на Мармароші (раніше не було точних відомостей про наявність даного таксону в Українських Карпатах), Noccaea dacica на Чорногорі (раніше наводився лише для Свидівця), Oxytropis carpatica на
\end{abstract}


А. Новіков

ISSN 0206-5657. Вісник Львівського університету. Серія біологічна. 2018. Випуск 78

Чорногорi, Scorzoneroides pseudotaraxaci на Чорногорі та Гриняві (раніше наводився лише для Свидівця), а також Trifolium sarosiense на Чорногорі та Свидівці (раніше не було точних відомостей про наявність даного таксону в Українських Карпатах). Таким чином, в Українських Карпатах наявні щонайменше 76 ендемічних і субендемічних таксонів, а ще трьох таксонів (Dianthus spiculifolius, Leucanthemopsis alpina та Trisetum macrotrichum) скоріше за все немає, хоча вони й згадуються інколи в літературі.

Ключові слова: Карел Домін, ендемічні рослини, біогеографія, збереження рослин, Карпати 